you have the college, but where are the day students? You are blinding your eyes to facts: you have no boys in Belfast who are prepared for modern business life in your schools; you have no boys fit to begin study at this college. The sooner you set about such a kind of school work as is necessary the better.

I do not know what the Model School is like now, but fifty years ago it produced better boys of the kind that you now want than any school in the world.

If you would sink your pride, and as a temporary measure take here in the day time boys of fourteen and teach them until they were seventeen, showing Ulster how good modern-school teaching might be given, I feel sure that you would make a rapid success. But such school work ought to last only until your example would be followed by outside schools. It strikes me, in fact, that you ought to show both the primary and the continuation and the secondary schools what they ought to do.

There are now quite a number of secondary schools in England and Scotland which provide science colleges with just such intelligent students as they want. Our unscientific rulers have given an Intermediate Board to Ireland which takes care that there shall be no such schools here. Nearly all the great English public schools have made a vigorous attempt to give the kind of education which is needed, but unfortunately the movement languished because it is opposed to all the traditions of such schools, and there are things like Latin which no schoolmaster will part with. This is the reason why the modern sides of the English public schools are such failures.

Your difficulty here is felt in many other places, but in some other places it has been grappled with and conquered.

I repeat, it is in your power to make this the great science school of the University, not merely developing applied science, but developing scientific discovery in both physical and biological science; but your schools do not yet prepare bovs for such studies.

At present the Queen's University of Belfast refuses to recognise your students unless they pass entrance examinations in Latin and French or Latin and German. The time is coming when you yourselves will be able to confer a science degree on your cleverest students, the students who have had sufficient self-respect to neglect subjects which for them were not educational.

\section{MOMENTUM IN EVOLUTION.'}

$\mathrm{I} T$ is a fact well known to palæontologists that many widely separated groups of the animal kingdom have, during the course of their evolution, and especially towards the end of that course, shown a strongly marked tendency to enormous increase in size. ${ }^{2}$ We see this in the extinct eurypterids, giants amongst the arthropoda, in the huge labyrinthodont amphibians, in many reptiles of the Secondary period, some of which attained a length of 180 feet or more, and amongst mammals in the extinct Tinoceras and the still surviving elephants and whales.

Comparative anatomists are familiar with similar phenomena exhibited by individual organs, such as the extraordinary development of horns and spines on many of the extinct reptiles referred to, the gigantic and grotesque beak and helmet of the hornbili, and the tusks of Babirusa. ${ }^{3}$

The exuberant development of some organs of this kind may possibly be attributed to the action of sexual selection, and, indeed, our daily experience of our own species seems to warrant us in believing that there is no limit to the grotesque results which may ensue from the unrestricted exercise of the æsthetic faculties by either sex; but it scarcely seems reasonable to attempt to explain all such bizarre and monstrous productions in this manner.

In all the cases cited, and in many others which could be adduced, either the entire body or some particular

1 Paper read before the Section of Zoology of the British Association at the Portsmouth meeting by Prof. Arthur Denny, F. R.S.

2 Vide Dr. Smith Woodward's presidential address to the Geological Section of the British Association, I9o9.

${ }^{3}$ Darwin supposed that these tusks, which are curved backwards in such a position as to render them useless as weapons of offence, might still be defensive and used to parry blows, but this scarcely seems sufficient explanation of their enormous development.

NO. 2200 , VOL. 88$]$ organ appears to have acquired some sort of momentum by virtue of which it continues to grow far beyond the limits of utility, although perhaps in some cases a new use may be found which will assist the species in maintaining itself in the struggle for existence. An enormous increase of mere bodily size, however, seems in the long run to be always fatal to the race, the place of which will be taken by smaller and presumably more active forms. The gigantic amphibians are all extinct, so are all the really gigantic reptiles; and of the gigantic mammals only a couple of species of elephants and a few whales survive, all of which are being rapidly exterminated in competition with man.

Is there any justification in recent developments of biological science for the belief that a race of animals may acquire a momentum of the kind referred to which may ultimately lead it to destruction? Is there some brake normally applied to the growth of organisms and organs, and, if so, are there occasions on which the brake may be removed, leaving the organism to rush to destruction like a car running away downhill? I hope to be able to show some ground for believing that both these questions may be answered in the affirmative.

It is, I think, now generally accepted by physiologists that the growth of the different parts of the animal body is controlled by internal secretions or hormones, the products of various glands. Thus we know that disease of the pituitary body in man leads to acromegaly, one of the symptoms of which is great enlargement of certain parts. The most dreadful of all diseases to which human beings are liable, cancer, is essentially due to an unrestrained multiplication of cells, and consequent abnormal growth of tissue, which may very possibly be correlated with the extent to which some specific controlling secretion is produced in the body. In short, we are justified in believing that, in the individual, growth is normally inhibited or checked by specific secretions, and that in the absence of these it will continue far beyond the ordinary limits.

The question next arises, Can we apply this principle to the race as well as to the individual? I see no reason why we should not do so, and, paradoxical as it may seem, I think we may be able to explain the growth of the organism as a whole, and of its various organs, beyond the limits of utility, as an indirect result of natural selection.

When a useful organ, such as the tusk of a wild boar, is first beginning to develop, or to take on some new function for the execution of which an increase in size will be advantageous, natural selection will favour those individuals in which it grows most rapidly and attains the largest size in the individual lifetime. If growth is normally checked and controlled by some specific secretion, natural selection will favour those individuals in which the glands which produce this secretion are least developed, or at any rate least active. This process being repeated from generation to generation, these glands (whatever may be their nature, and we may use the term gland for any cell or group of cells which produces a specific secretion, whether recognisable as a distinct organ or not) may ultimately be eliminated, or at any rate cease altogether to produce the particular hormone in question. Moreover, this elinination may take place long before the organ the growth of which is being favoured by natural selection has reached the optimum size. When it has reached this optimum it is certainly desirāble that it should grow no larger; but there is no longer any means by which the growth can be checked: the inhibiting hormone is no longer produced, the brake has been removed, and further growth will take place, irrespective of utility, until, when the size of the organ gets too great to be compatible with the well-being of the individual, natural selection again steps in and eliminates the race. The same argument, of course, applies to the size of the body as a whole, as well as to that of its constituent organs. Is it not possible that, the normal checks to growth, being thus removed along certain lines by the action of natural selection, a definite direction may be given to the course of evolution which the organism will continue to follow, irrespective of natural selection?

I shall probably be told that all organs vary, and that when any particular organ has reached the optimum size 
natural selection will prevent it from going further by eliminating the unfavourable variations, i.e. those which exhibit further increase. It may be admitted that the organ in question will probably exhibit variation in size after reachirs the cptimum, due to differences in nutrition and other peculiarities of the individual environment; but I fail to see how, in the absence of the gland which produces the specific controlling secretion, and which we have assumed to have been already eliminated, there are likely to be any variations of a minus character suitable for natural selection to work upon. In other words, it appears to me probable that natural selection, having once let go her control of growth, would be unable to regain it. In order that she might do so, it would be necessary either that the glacdular organ which originally produced the inhibiting hormone should be again developed or that some other organ should take its place. It is, however, generally admitted that an organ, once lost, is never redeveloped, and it does not seem likely that any other glandular organ, which we may suppose to be already occupied in producing a specific secretion for some other purpose, would be able to take on new duties and provide the necessary control before it was too late to save the organism from destruction.

If there is a possibility of any cumulative effect from generation to generation there seems no reason why, in these circumstances, increase of size should not continue indefinitely until it becomes incompatible with existence. Have we any right to assume any such cumulative effect? I think we have, for we know very well that the whole ontogeny of any one of the higher animals is nothing but the accumulation of a number of successive stages which have been added one after the other in the individual lifetimes of past generations. This, at any rate, is the teaching of the recapitulation hypothesis, in the truth of which $\mathrm{I}$, for one, am a convinced believer. We also know from the facts of embryology that as each successive stage is added there is a tendency both towards an increase in the length of time occupied in development and also towards compression and abbreviation of the earlier stages, so as to make room for new chapters of the record.

It seems, therefore, not unreasonable to assume that any increment in size which is gained by an individual animal or one of its organs before the period of reproduction, or before the germ cells which will give rise to the next generation are matured, and which is the result of the removal of some controlling factor, will tend to be inherited in the offspring in a cumulative fashion. If not, why have other features in the ancestral history been accumulated by heredity? It may be said that after the maximum rate of growth has once been attained there will be no further increase in the size of the organ; but I think there will, if only because there will be a slightly increased time available, owing to the lengthening of the period of development in which growth may take place. Then, even if there is no further acceleration of 'the actual rate of growth after the controlling influence has once been completely removed, the lengthening life-history will still afford opportunities for increase of size. It seems not impossible, however, that acceleration might also continue in connection with the shortening up of the stages of development in the ontogeny.

I should like to meet in advance another objection which may be raised to the views herein advocated. It may be urged that many of the bizarre and almost monstrous characters under discussion, such, for example, as some of the excrescences of the dermal armature in extinct reptiles, can never have had any value as adaptations, and that therefore natural selection could never have encouraged them to increase so much in size as to get beyond her control. Here, however, the principle of correlation comes in. Just as many different parts of the body are affected by disease of the pituitary gland, so the removal of the gland which controlled the development of some undoubtedly useful organ, such as a frontal horn, might at the same time permit the growth of all sorts of excrescences which have no adaptive significance.

I need hardly say that I have no wish to speak dogmatically with regard to the cause of that remarkable momentum which organisms certainly seem in many cases to acquire during the course of their evolution. Our knowledge of internal secretions and their specific action upon the different parts of the body is still in its infancy; indeed, it has hardly commenced; but I venture to point out to biologists a possible clue to what has been for a long time an insoluble enigma. I hope that my suggestion will be freely criticised, and that it may give rise to a discussion from which some grain of truth will ultimately emerge.

\section{UNIVERSITY AND EDUCATIONAL INTELLIGENCE.}

LORD HALdANE has beer elected Chancellor of the University of Bristol, in succession to the late Mr. Henry Overton Wills.

ThE Clothworkers' Company has supplemented its previous grant of $500 l$. to the Bedford College for Women Building Fund by a further grant of $500 l$.

REUTER reports that the council of the University of Paris has sanctioned a scheme for an exchange of students between the Universities of Paris and London.

THE Paris correspondent of The Times announces that the Marquise Arconati-Visconti has endowed the University of Paris with the sum of $20,000 l$., which is to be employed for the benefit of the faculties of medicine and of letters.

THE annual meeting of the Mathematical Association will be held on Wednesday, January Io, I9I2, at the London Day Training College, Southampton Row, London, W.C. There will be an address by the president, Prof E. W. Hobson, F.R.S., and the following papers will be read:-on the work of the International Commission on Mathematical Teaching, $C$. Godfrey; on some unrealised possibilities in mathematical education, G. St. L. Carson a plea for the earlier introduction of the calculus, C. V. Durell.

IN August last Mr. Snowden, M.P., sent the Prime Minister a memorial, signed by more than 400 members of the House of Commons, urging that the time had come for a new inquiry into the system of appointment and the method of promotion in the Civil Service. The Prime Minister has now replied that the Government has come to the conclusion that such an inquiry, by a Royal Commission, would be useful and opportune. The composition of the commission and the terms of reference will be announced in due course.

We learn from The Pioneer Mail that the Government of India has decided to place Lieut.-Colonel E. H. V. Atkinson, R.E., principal of the Thomason College, Rorkee, and Mr. T. Dawson, principal of the Victoria Technical Institute, Bombay, on special duty early. in the new year. The object of the special duty is to bring the technical institutions of India into closer practical relations with the employers of labour in the country, whether they be Government workshops or factories or private concerns. Colonel Atkinson and $\mathrm{Mr}$. Dawson will study the existing requirements of employers of labour, and how far they can be met at existing institutions. They will also make proposals for establishing closer connection between the existing business concerns and the existing technical institutions. On entering any province they will report themselves to the local government, and conduct their inquiries on lines approved by the local government and in the company of any person whom the local government may appoint for the purpose. It is hoped that employers of labour will cooperate with the Government in this important practical work.

THE necessity for the establishment in this country of a lectureship in tropical agriculture forms the subject of a leaflet which has been circulated by Mr. S. Simpson, of 49 Finsbury Pavement, London, E.C., and a copy of which has been received. The departmental committee appointed in 1908 by the Board of Agriculture and Fisheries to inquire into and report upon the subject of agricultural education in England and Wales, put on 